\title{
EDITORIAL
}

Linguagens: Revista de Letras, Artes e Comunicação dedica-se, neste número, à área de Comunicação, tratando de cinema, cultura digital, ética, TV, Filosofia e Comunicação, linguagem publicitária, linguagem jornalística, literatura e jornalismo. Em "Imagem amadora no telejornalismo em tempos de cultura digital”, Fábio Cadorim investiga se a relevância do valor-notícia visualidade no telejornalismo sofre impacto com a implantação da TV digital. Os resultados sugerem que a importância do valor-notícia visualidade no telejornalismo não é impactada pela implantação da TV digital, mas que está relacionada ao ingresso na cultura digital. Os dados também apontam para o fortalecimento do jornalismo participativo e da audiência como coautora da produção noticiosa de televisão. Tendo como autor da pesquisa Iuri Yudi Furukita Baptista, a arqueologia do saber formulada por Michel Foucault é aqui apresentada como uma opção metodológica para a pesquisa no campo da comunicação. O autor aposta na maleabilidade da metodologia, mostrando que ela pode ser aplicada a diversos estudos do campo comunicativo. O estudo "A hermenêutica de profundidade e suas aplicações”, de Heleno Rocha Nazário, Luciana da Silva Souza Reino e Rodolfo Manfredini, destaca que a pesquisa na área da comunicação pode ser direcionada para as diferentes etapas do processo comunicativo, como a produção, a circulação, a recepção e o retorno - ou os efeitos das mensagens no meio social - e aposta no referencial teórico proposto por John B. Thompson, a hermenêutica de profundidade, como uma opção válida para as pesquisas nesse campo do conhecimento. No ensaio "O conceito de extracampo no cinema: o plano do invisível", Ricardo Weschefelder destaca que o plano cinematográfico, seja em enquadramento fixo ou móvel, é o território que promove a dialética entre o interior e exterior da cena. $\mathrm{O}$ autor traz uma discussão sob a perspectiva do simbólico, em diálogo com Walter Benjamin, vendo o plano como camada, estado e dimensão da imagem. Em "O apogeu e a crise da programação infantil na televisão brasileira: as adaptações do Sítio do Pica-pau Amarelo" Jeferson Balbino e Marcela Verônica da Silva traçam o perfil dessa programação ao longo do tempo, desde o seu surgimento no Brasil até os dias atuais. Para tanto, tomam como exemplo as diversas adaptações d'O Sítio do Picapau Amarelo de Monteiro Lobato para a televisão, em especial a última versão produzida pela TV Globo em 2001. No artigo "Made in Brazil: entre os laços das migrações na identidade da música brasileira dos anos 1970”, os autores Jackson Gil Ávila e Jussara Bittencourt de Sá procuram refletir sobre as migrações na identidade 
musical brasileira dos anos 1970. A pesquisa focaliza artistas que fizeram parte do movimento Made in Brazil e das associações que foram estabelecidas com o mercado fonográfico e com a televisão, mais especificamente com as novelas e suas trilhas sonoras. Como recorte para estudar o movimento Made in Brazil, elegeram os cantores Fábio Júnior (Mark Davis e Uncle Jack), Chrystian e Michael Sullivan, além do grupo musical Pholhas. O ensaio "Alterações na identidade feminina à luz da mídia televisiva dos anos 80", de Adriana Conceição Silva Costa, reflete sobre a identidade feminina na mídia televisiva e suas possíveis alterações visualizadas através de personagens protagonistas de uma novela e uma série - a saber: Roque Santeiro e Malu Mulher - veiculadas na década de 1980 na televisão brasileira. O período é pontuado pelo fim da censura imposta pela ditadura militar no Brasil e pelo período de leve abertura democrática. No estudo "Mídia e midiatização em Notícia de um sequestro", os autores Marcelo Fernando de Lima e Amanda Arruda Venci partem da ideia de que mídia e poder estão intimamente vinculados e de que os meios de comunicação sempre exerceram influência sobre diversos acontecimentos, moldando eventos através dos tempos. Os autores discutem o conceito de midiatização a partir de Notícia de um Sequestro (1996), de Gabriel García Márquez. A obra apresenta o relato de um caso em que a mídia assume a posição de protagonista, tornando-se, de certa forma, um tema do livro. Dessa maneira, pretendem discorrer sobre a importância do papel da mídia como elemento de negociação, manipulação e disputa de poder. "Conexões históricas entre Linguagem e Jornalismo", de autoria de Carlos Borges Junior, aponta conexões históricas que permitem discutir o jornalismo enquanto ato singular de língua(gem). A discussão bibliográfica investiga desde o registro de informações nas paredes das cavernas, na Grécia pré-socrática, na Idade Média, Renascimento e Iluminismo, até o período contemporâneo. "Jornalismo, ciência e interdisciplinaridade: notas sobre o informar e produzir conhecimento", de autoria Jeferson Bertolini, pensa o jornalismo no contexto da ciência e da interdisciplinaridade. $\mathrm{O}$ objetivo é dizer que, além de informar, o jornalismo produz conhecimento, como faz a ciência. O texto aponta as faces inter, multi e transdisciplinar do jornalismo - que tem pelo menos duas características em comum com a ciência: a produção de conhecimento e a busca pela verdade. "Resistência e jornalismo na literatura de Antonio Callado", do autor Marco Aurelio Reis, é um estudo que destaca que, após meio século do golpe militar no Brasil, a obra do jornalista e escritor Antonio Callado surge como importante elemento de reconstrução do período de censura a jornais. Três romances do autor (Quarup, Bar Don Juan e Reflexos do Baile), escritos após1964, aparecem como elementos reflexivos sobre 
resistência armada ao golpe e também como obras de militância intelectual em prol da democracia. A proposta é reabrir o debate em torno dos três romances, convidando para uma releitura crítica deles, nesse novo momento histórico em que a memória da ditadura tem o relevante papel de impedir a repetição daqueles tristes episódios. No ensaio "Forma de vida feminina na Revista Você S/A: uma análise semiótica do percurso de empoderamento do ator mulher executiva contemporânea", de Raíssa Oliveira e Edna Nascimento, busca compreender - com base no aparato teórico-metodológico da semiótica francesa, principalmente nos recentes estudos acerca das "formas de vida", conceito que tem motivado uma ampliação da noção de "ator" - o percurso de empoderamento do ator mulher executiva contemporânea dentro do cenário corporativo brasileiro. Três matérias veiculadas na revista VOCÊ S/A foram selecionadas para análise: "Mulheres no poder", "Garotas Superpoderosas" e "As rainhas da Ambev". A hipótese inicial das autoras, confirmada ao final das análises, mostra que papéis e comportamentos tradicionalmente femininos são reiteradamente valorizados pelo enunciador do periódico, fortalecendo a figura mítica da mulher que concilia diferentes papéis sociais, mantendo a beleza e a sensibilidade. "Carta maior e Veja: silenciamento no caso Charlie Hebdo", de autoria de Marilia Manfredi Gasparovic, traz, à luz da análise do discurso de linha francesa, as formações discursivas mobilizadas nos discursos das revistas Veja e Carta Maior, por meio de duas colunas opinativas, em relação ao atentado contra o periódico satírico francês Charlie Hebdo, ocorrido no início de 2015. As revistas Veja e Carta Maior, por se inscreverem em formações discursivas distintas, não apontaram as mesmas causas para o atentado. Nesse sentido, o trabalho busca compreender como se deu a construção discursiva no que tange às causas do ataque, em dois veículos de comunicação com posições ideológicas distintas, e procura dar abertura a novas discussões sobre a temática. A Revista Linguagens deseja a todos ótimos momentos de leitura e espera contribuir com os estudos na área de Comunicação!

\section{Maria José Ribeiro}

Editora 